\title{
Az úszóváll hatékony prevenciójának sportfizioterápiás vonatkozásai
}

\author{
SZABÓ DOROTTYA', DR. LÁZÁR ISTVÁN², DR. MINTÁL TIBOR ${ }^{1,3}$ \\ DR. GÖCZE KATALIN ${ }^{1}$
}

\section{ÖSSZEFOGLALÁS}

Az úszók körében leggyakrabban előforduló mozgásszervi probléma az úszóváll néven ismert patológia, amely az ízület elülső régióját érintő fájdalom formájában jelentkezik. Az összefoglaló közlemény ennek az entitásnak az epidemiológiai jelentőségét és etiológiáját tárgyalja, az elérhető hazai és nemzetközi szakirodalomban leírtaknak megfelelően, ezáltal szerkezetét tekintve eltér a klasszikus felosztástól. Prevenciós és rehabilitációs ajánlásokat fogalmaz meg a hazai és a nemzetközi kutatási eredmények alapján, illetve átfogó képet ad egészségügyi és sportszakmai vonatkozásokban a téma sportfizioterápiás megközelítésú megismeréséhez.

\section{Kulcsszavak: $\quad$ Fizioterápia; Sportolók; Úszás; Vállfájdalom; Vállizület;}

D. Szabó, I. Lázár, T. Mintál, K. Göcze: Effective functional prevention of swimmer's shoulder: principles of sports physiotherapy

Swimming is one of the most popular sports in the world enjoyed by millions of fans in and outside of the pool. Anterior shoulder pain is the most common musculoskeletal problem affecting the health and performance of competitive swimmers of all ages. The aim of this scientific review is to summarise the aetiology of this injury with the intention to discuss recommendations on effective prevention and rehabilitation strategies from the perspective of sports physiotherapy giving comprehensive and evidencebased guidelines for the medical team taking care of swimmers.

Keywords: $\quad$ Athletes; Exercise therapy; Shoulder joint - Physiology; Shoulder Pain - Etiology; Swimming - Injuries; 


\section{BEVEZETÉS}

Az úszók körében leggyakrabban előforduló krónikus mozgásszervi tünetegyüttes a váll elülső régiójának fájdalma, amelyet először Kennedy és Hawkins írt le úszóváll néven 1974-ben (6). Az, hogy maga a fogalom már 45 éve a szakirodalomban fellelhető, és az, hogy a sportolókkal dolgozók ez irányú ismeretei sokszor kimerülnek abban, hogy a fájdalom a versenysporttal együtt jár, adja a téma jelentőségét. Vezető tünete az edzés ideje alatt és után fellépő fájdalom, amely az úszó edzés- és versenyteljesítményére, illetve hétköznapi életvezetésére egyaránt hatással van. Előfordulási gyakorisága versenyúszók körében 40,91\%-ra tehető (kortól, nemtől, illetve a terhelés mértékétől függően), amely igen magasnak mondható (17). Számos nemzetközi közlemény foglalkozik elméleti és gyakorlati szinten a primer és szekunder prevenció jelentőségével és ad támpontot az integrált megelőzési stratégiákat illetően $(5,7,8,13,15,17)$. Serdülőkorú úszók esetében ennek jelentősége kiemelten fontos, mivel az intenzív növekedési periódus a testalkat jelentős kvantitatív és kvalitatív változásaival jár együtt. Vizsgálatunk célja az volt, hogy a nemzetközi és a hazai szakirodalom szisztematikus áttekintését követően, azok alapján, olyan sportfizioterápiás szakmai ajánlást fogalmazzunk meg, amellyel hatékonyan tudjuk támogatni a hazai úszósportot és sportolóink sikeres felkészülését, így segítve aktív versenyzői karrierjük kiteljesedését/maximalizálhatóságát.

\section{KOCKÁZATI TÉNYEZŐK}

$\mathrm{Az}$ állapot kialakulásáért elsősorban az úszósportra jellemző folyamatos, fej feletti mozdulatsor felelős. Az úszó vállízületének terhelése egy átlagos edzés alatt 10000-15000 méter, ez körülbelül 4000 kartempót jelent, heti 6-7 alkalommal (7). A vállat ért terhelés mértéke úszásnemenként eltérő, azonban az edzésidő $80 \%$-ában a gyorsúszás technikájával úsznak. Ebben az úszásnemben a propulzív erő 80\%-ban a felső végtag erőkifejtéséből adódik és csak a maradék $20 \%$-át teszi ki a lábtempó során kifejtett erő. A többi úszásnem esetében ezek az előre hajtó erőarányok a következőképpen alakulnak: $50 \%-50 \%$ a mellúszás, $70 \%-$ $30 \%$ a pillangó és $75 \%-25 \%$ a hátúszás során (3). Ebből következik, hogy gyorsúszás során fokozott terhelés helyeződik a rotátorköpeny izmaira és a $\mathrm{m}$. biceps brachii hosszú fejének inára. Az ismétlődő mikrosérülések idővel öszszeadódnak, amely fájdalom, gyulladás és különféle lágyrész-patológiák megjelenését vonhatja maga után (8). Kóroki szempontból egyéb anatómiai és biomechanikai okok szerepe is kiemelhető. Az úszóváll esetében multifaktoriális kórképről beszélünk, amely rizikótényezőit két fő csoportba sorolhatjuk (I. táblázat).

Az úszóváll nem egy konkrét diagnózis, hanem számos patológia önálló vagy együttes megjelenését jelenti. Ezek azonosításának a rehabilitáció és prevenció szempontjából differenciáldiagnosztikai jelentősége van. A leggyakrabban előforduló kórképek a váll elülső fájdalma esetében: a m. biceps brachii hosszú fej inának tendinitise, az érintett váll impingement szindrómája, vagy a glenohumeralis ízület instabilitása (8).

I. táblázat Az úszóváll kialakulásában szerepet játszó belső és külső kockázati tényezők (15)

Intrinsic tényezók

fokozott generalizált ízületi lazaság

tartási rendellenességek

elégtelen törzserő

scapula dyskinesis

\section{Extrinsic tényezők}

edzésmennyiség okozta túlterhelés

hibás úszástechnika

inadekvát szárazföldi edzés

tenyérellenállás alkalmazása

glenohumeralis berotáció deficit

rotátorköpeny izmainak erőegyensúlyi eltolódása

korlátozott tok- és pectoralis izomzat flexibilitása 


\section{TESTTARTÁS-ELEMZÉS JELENTŐSÉGE}

A hajlamosító tényezőket megvizsgálva az utánpótláskorú versenyúszók körében kiemelt figyelmet érdemel a versenyzők habitualis testtartásának vizsgálata. Panaszmentes társaikkal összehasonlítva, a fájdalmat jelző úszókra nagyobb arányban jellemző a kifejezett háti kyphosis és a scapula dyskinesise (13). A biomechanikailag helyes testtartás egy olyan dinamikus egyensúlyi állapot, amelyet az izmok folyamatos aktivitása tart fenn és ezáltal az ízületi tok- és szalagrendszer feszülése fiziológiás. Amennyiben a törzsizmok csökkent aktivitása áll fenn és a szükséges egyensúlyt nem képesek fenntartani, úgy kialakulhatnak a gerinc sagittalis irányú elváltozásai, azaz a helytelen tartás (12). A testtartási rendellenességekkel az úszókra fokozottan jellemző „úszó testtartás" formájában találkozhatunk, amely leírásában a hanyag tartás kórképére ismerhetünk. Tartáshibáról akkor beszélünk, ha a gerinc sagittalis görbületei a fiziológiástól eltérőek, viszont aktív izomerővel korrigálhatóak, azaz mobilisak. Rögzült deformitások nem alakulnak ki és a csigolyaszerkezet nem mutat eltérést. A tartási hibák megléte esetén számolnunk kell az izmok elégtelen múködésével, hiszen a megváltozott biomechanikai viszonyok miatt feszülésük nem a fiziológiásnak megfelelő (12). Ezekből a látható funkcionális eltérésekből feltételezhetjük a thoracalis szakasz mozgásainak korlátozottságát, amelyet szintén az úszóváll kialakulásának lehetséges okának írnak le (13). Ezen kívül a megtapasztalt testtartási rendellenesség a thoracalis gerinc paravertebralis izomzatának és a lapockát stabilizáló és záró izmok gyengeségét, valamint a $\mathrm{m}$. pectoralis minor és major rövidülését is jelentheti. Ennek megfelelően a fentiekben felsorolt intrinsic (izomerő diszbalansz, megváltozott mozgásterjedelem) faktorok (az ízületi lazaságot kivéve), a tartási rendellenesség mintegy következményeiként egyrészt fenntarthatják a kialakult tartási hibát, valamint az úszók vállfájdalmának állandósulásában is szerepet játszhatnak. Az állapot reverzibilis volta lehetőséget teremt a kialakult abnormalitás kijavítására, ami célzott, adekvát intervenció révén sikeresen elérhető.

\section{FOKOZOTT ÍZÜLETI LAZASÁG SZEREPE}

Az úszóvállal foglalkozó szakemberek körében máig erősen vitatott, hogy a sportoló számára előnyt jelent-e a vállízület fokozott laxitása, viszont a hatékony úszáshoz elengedhetetlen ízületi lazaság az úszók csak mintegy 20\%-ánál veleszületett. A többi sportoló az extrém nagy mozgáspályákat a sportmozgás és még inkább a sokszor drasztikus nyújtógyakorlatok rendszeres végzésével éri el. Vizsgálatok sora bizonyítja, hogy az ízület lazasága elősegíti a fájdalom és a különböző lágyrész-patológiák megjelenését $(3,4,13)$. Kijelenthetjük azonban, hogy amennyiben az extra mértékú mozgáspályák elérését célzó stretching során a passzív stabilizátorok anatómiailag és funkcionálisan károsodnak, az megnöveli az ízület aktív stabilitását biztosító izmok jelentőségét (17). Irodalmi adatok alapján a váll sérülésének esélye megnövekszik, amennyiben a 90 fokos abdukciós helyzetben mért kirotáció mértéke meghaladja 100 fokot, illetve ha 93 fok alatti. Bármelyik állapot fennállása esetén az úszóváll kialakulásának veszélye növekedhet (17). A váll berotációjának csökkenése a tok hátsó részének zsugorodása következtében alakulhat ki, ezzel növelve a humerus anterior irányú csúszásának lehetőségét. Ebben az esetben számolni kell a másodlagos impingement szindróma veszélyével. A 60-70 fok berotációs mozgásterjedelem az úszók esetében normál tartománynak számít, amelytől felfelé vagy lefelé való eltérés megnöveli a vállpanaszok kialakulásának esélyét (2). A váll passzív, flexiós mozgásterjedelmének elmaradása szintén utalhat olyan lágyrész-képletek rövidülésére, amelyek befolyásolhatják a megfelelő úszástechnikát, és akár a fájdalom forrásává is válhatnak $(3,4,16)$, ezért ennek felmérése is szükséges az úszók sérülésrizikójának megítélése szempontjából.

\section{HELYTELEN ÚSZÁSTECHNIKA: OK- OKOZATI ÖSSZEFÜGGÉSEK}

Az úszóváll kialakulásában szerepet játszó tényezők teljes áttekintéséhez szükséges, hogy az úszásnemek közül a gyorsúszás helytelen technikai kivitelezéséből adódó következményeket is megismerjük. A gyorsúszás karmunkáját víz feletti és víz alatti szakaszokra osztjuk 
fel. A mozdulatsor bármely szakaszában megjelenő, hibás úszástechnika az optimálistól eltérő izommunkával és túlterheléssel jár, amely repetitív stresszhatásként következményekkel járhat. Helytelen technikai kivitelezés alatt a víz feletti áthúzás során az elégtelen törzsrotációt, míg a víz alatti karmunka esetében a kéz vízbe érésekor tapasztalt középvonalon túli vagy túlságosan előrenyúló karcsapást értjük. Mindegyik esetben a subacromialis tér beszűkül, amely impingement szindróma kialakulását, valamint a rotátorköpeny folyamatos irritációját okozhatja (15). Izomdiszbalansz nem csak helytelen technika mellett jelentkezhet, hanem önálló entitásként is hozzájárulhat az úszóváll kialakulásához, ugyanis a meglévő izomerő és izomtónus eltolódás az izmok gyors kifáradása révén hibás technikai elemek megjelenéséhez vezethet. Az így kialakuló circulus vitiousus csak megfelelően felépített prevenciós tréning következetes bevezetésével és az esetlegesen meglévő rossz úszástechnika fokozatos kijavításával lehet megszakítani.

\section{SERDÜLÖKOR}

Utánpótláskorú sportolók esetében számolnunk kell a serdülési növekedési lökés idején végbemenő testméretek és testarányok változásával, amelynek következménye a mozgások biomechanikai feltételeinek megváltozása és így a motorikus képességek átmeneti visszaesése. Az időszaknak a jelentőségét a hosszú távú sportolói karrier szempontjából az adja, hogy az utána következő stabilizálódási és egyéni mozgásmintázat-kialakulási időszak alapját és a versenyző testének optimális felépítését ilyenkor befolyásolhatjuk. Az átalakulás következményeit a rendszeres, jól megtervezett és a korosztálynak megfelelő szárazföldi tréningekkel, valamint a kondicionális képességek adekvát fejlesztését szem előtt tartó, vízben eltöltött edzésekkel korrigálhatjuk (1).

\section{MEGELÖZÉS}

\section{Elméleti és gyakorlati aspektusok}

A fentiek alapján feltételezhető, hogy az úszóváll kialakulását számos tényező együttes hatása idézheti elő. Ezek pontos ismerete teremti meg a primer prevenció lehetőségét, amely alkalmazása támogatja a fiatal sportoló hosszú távú sérülés- és fájdalommentes felkészülését, biztosítva ezzel a versenysportban való eredményes helytállását a folyamatos terhelés- és teljesítménynövekedés mellett is (15).

Az elméleti és gyakorlati eredmények szintézise és a sportolók folyamatos nyomon követése segíti a rövid és hosszú távú célok megvalósítását, a sportbalesetek és a degeneratív elváltozások kialakulásának megelőzését, azok kialakulási valószínűségének csökkentését. Krónikus vagy perzisztáló fájdalom esetén, a további eltérések megelőzése, illetve a másodlagos károsodások kialakulásának elkerülése érdekében elsősorban a kockázati tényezők felmérése és eliminálása szükséges. A rizikófaktorok teljes kiiktatása gyakorlatilag lehetetlen, viszont az edzők és a sportolók részére számos preventív lehetőség áll rendelkezésre, melyekkel a sérülés kialakulásának esélye csökkenthető (10).

\section{Progresszív prevenciós tréning elemei}

Az alábbiakban olvasható összeállítás hazai és nemzetközi vizsgálatok eredményei alapján készült ajánlás, amely szerint a gyakorlatban történő implementáció során kiemelten fontos a korspecifikus koordináció és mozgáskészség figyelembe vétele és a fejlesztés ennek megfelelő tervezése. Fontos megemlíteni, hogy a probléma multifaktoriális eredete miatt nem lehet kiemelni egy-egy gyakorlatot, ami átfogó megoldást nyújtana. Éppen ezért szükséges, hogy a megfelelő ismeretek birtokában, a sportfizioterápiában jártas gyógytornász foglalkozzon a prevenciós tréningek kivitelezésével. Ezzel biztosítva a tréningek során az életkornak és aktuális állapotnak megfelelő terhelést és egyben az összterhelés változatlansága mellett a gyakorlati anyag változatosságát is.

\section{Törzs izmainak megerösítése és stabilizálása}

Az úszók körében igen gyakori jelenség a fokozott háti kyphosissal, a kifejezett vállövi protractióval és a fej előre helyezettségével jellemezhető testtartási rendellenesség $(7,13)$. 
A biomechanikailag helyes testtartás elérése érdekében a törzset tartó és mozgató izmok progresszív erősítő és stabilizáló tréningje elengedhetetlen része a preventív programnak, mivel a proximalis stabilitás feltétele a későbbi optimális végtagi funkcióknak a sportmozgások során. Ezen felül a serdülőkori növekedés következményeként kialakuló visszaesés a relatív izomerőben, a törzs stabilitásában és a motoros kontrollban szintén szükségessé teszi (1), hogy fókuszpontba kerüljön a törzs ilyen irányú fejlesztése. Ennek elmaradása esetén az ebben a korban kialakuló testtartási rendellenességek a későbbiekben irreverzibilissé válhatnak és ez a sportoló hosszú távú, fájdalommentes és sikeres sportkarrierjét befolyásolhatja.

\section{Lapockát stabilizáló és záró izmok megerösítése}

A vállöv normálistól eltérő kinematikáját nevezzük a scapula dyskinesisének, amelynek előfordulási gyakorisága a serdülőkorú úszók körében 30-57,1\%-ra tehető, de akár egy edzésen belül az edzés elején felmért gyakorisághoz képest elérheti akár a 80\%-ot, az érintett izmok kifáradásának következtében $(9,14)$. A scapula dyskinesis összefüggést mutat a váll fájdalmának megjelenésével és a vállfájdalom mögötti patológiával is. Okai között szerepelhet a csontok megváltozott anatómiai helyzete, az ízületek instabilitása vagy a lágyrészek rugalmatlansága. A scapula dyskinesis látható jele a lapocka elemelkedése a mellkasról (winging) és a váll-vállövi komplexum mozgásai során a megváltozott lapocka-kontroll (diszritmia) (9). A régió fejlesztése kiemelten fontos, mivel a lapockát mozgató és stabilizáló izmok edzés közbeni kifáradása a vállízület túlterhelődéséhez vezethet. A $\mathrm{m}$. serratus anterior és a $m$. subscapularis túlterheléséből adódó kifáradása és a fájdalom megjelenése közti összefüggést EMG vizsgálatokkal is alátámasztották (11). Ennek kialakulása a $\mathrm{m}$. serratus anterior, a m. rhomboidei, a m. trapesius pars medius és pars inferior részének progresszív erősítésével és stabilizáló tréningjével megelőzhető.

\section{Váll körüli izmok megerösítése és proprioceptiv tréningje}

A szakirodalom részletesen foglakozik a vállízület ki- és berotációs izomerejének felmérésével. Ezeket összegezve elmondható, hogy a hangsúly sokkal inkább az antagonista izomcsoportok erejének arányán, mint magán az abszolút izometriás izomerő nagyságán van. A be- és kirotációért felelős izmok egyensúlya biztosítja a humerus statikai és kinematikai szempontból is optimális helyzetét. Serdülőkorú versenyúszóknál ez az ER:IR hányados 73-77\% közötti értéket mutat (5). A ki- és berotációs erők viszonyának felmérését és folyamatos utánkövetésének jelentőségét azért kell hangsúlyozni, mert amennyiben ez az arány $50 \%$ vagy az alatti, a kirotátorok már nem tudják a megfelelő, kellően centrális pozícióban stabilizálni a humerus fejet (4). Adekvát gyakorlatok kiválasztásával fokozatosan és átfogóan erősíthetők a rotátor köpeny izmai, aminek jelentőségét az adja, hogy a ki- és berotációt végző izmok diszbalansza a glenohumeralis ízület instabilitásához vagy impingement szindróma kialakulásához vezethet. Fokozott sérüléskockázat miatt külön kiemelendő a m. supraspinatus, mert annak csökkent izomereje, inának tapadási régiójára jellemző suboptimalis vérkeringése és tápanyagellátása akár következményes ínszakadáshoz vezethet. Az akut és krónikus sérülések a $m$. supraspinatus célzott fejlesztésével elkerülhetőek. A szükséges ízületi helyzetérzékelés az edzés közben jelentkező kifáradás miatt csökkenhet, amelynek következménye egyrészt a karcsapások hosszának rövidülése, másrészt a megváltozott úszástechnika. Ez is hozzájárulhat a vállízületi patológia kialakulásához. Ezen tényezők figyelembe vétele mellett, külön figyelmet kell szentelni a vállízület proprioceptív fejlesztésére.

\section{Rövidült izmok nyújtása}

Az izmok klasszikus felosztása szerint a tónusos csoportba tartozó izmok a túlterhelésre rövidüléssel, feszességgel reagálnak (1). Az úszók esetében ezek az izmok a m. latissimus dorsi, $\mathrm{m}$. pectoralis major és minor, a $\mathrm{m}$. trapesius pars superior. Egyéb lágyrészképletek közül jellemző még a glenohumeralis ízületi tok hátsó részének zsugorodása. A fent említett képletek statikus nyújtó gyakorlatai nélkülözhetetlenek, mivel rövidülésük a helytelen testtartási és váll-vállövi elváltozások fenntartásáért felelősek. Ezzel fokozva az úszóváll 
előfordulásának kockázatát (intrinsic faktorok: GIRD, csökkent flexió) (17).

\section{ÖSSZEGZÉS}

Áttekintő vizsgálatunk eredményei alapján elmondható, hogy a sikeres és a sérülések szempontjából zökkenőmentes utánpótlásnevelés a megfelelő személyi/ szakmai és tárgyi feltételek mellett sportorvosi és sportfizioterápiai irányelvek mentén valósulhat meg. Ennek elengedhetetlen eleme a rendszeres, standardizált szúrési protokollok bevezetése, szakszerű kivitelezése és elemzése. Hatékony intervenció kizárólag objektív, részletes állapotfelmérésekből kapott eredményekre alapozható. Ez nem csak a tervezést, de a folyamatos nyomon követést is lehetővé teszi. Kihangsúlyoznánk, hogy ezeknek a feladatoknak a kivitelezése nem tartozik az edzői kompetenciák körébe. Sokkal inkább egy sportfizioterápiában jártas gyógytornász irányításával, illetve a sportolók mellett folyamatosan jelenlévő sportfizioterápiás team komplex munkájával valósulhat meg. Mindent összevetve, a hosszútávon sérülésmentes és eredményes felkészülés az alapozási és versenyzési szezonhoz egyaránt adaptált (heti 2-3 $\times 30$ perc) szakmai protokollok irányadásainak megfelelően összeállított prevenciós mozgásprogramok révén biztosítható, amelyet csapatra, korosztályra vagy akár egyénre szabottan lehet alkalmazni.

A téma feldolgozása a Pécsi Tudományegyetem Klinikai Központ Regionális és Intézményi Kutatás-Etikai Bizottsága által kiadott, 6154 ügyiratszámú engedéllyel rendelkezik. 


\section{IRODALOM}

1. Balogh I.: Mozgás ABC. Kineziológiai alapismeretek. Izomstruktúra és funkció kapcsolata. Izmok felosztása funkció szerint. Budapest, 1999. 61 p.

2. Cools A. M., De Wilde L., Van Tongel A., Ceyssens C., Ryckewaert R., Cambier D. C.: Measuring shoulder external and internal rotation strength and range of motion: comprehensive intra-rater and inter-rater study of several testing protocols. J. Shoulder Elbow Surg. 2014. 23. (10): 1454-1461. https://doi.org/10.1016/i.jse.2014.01.006

3. De Martino I., Rodea S. A.: The swimmer's shoulder: Multy-directional instability. Curr. Rev. Musculoskelet. Med. 2018.11. (2): 167-171. https://doi.org/10.1007/s12178-018-9485-0

4. Fleisig G. S., Dun S., Kingsley D.: Biomechanics of the shoulder during sports. In: The athlete's shoulder. Eds. Kevin E. Wilk, Michael M. Reinold, James R. Andrews. 2. ed. Churchill Livingstone, Elsevier. 2009. 365-384. p. https://doi.org/10.1016/b978-044306701-3.50034-7

5. Hibberd E. E., Laudner K. G., Kucera K. L., Berkoff D. J., Yu B., Myers J. B.: Effect of swim training on the physical characteristics of competitive swimmers, Am. J. Sports Med. 2016. 44. (11): 2813-2819. https://doi.org/10.1177/0363546516669506

6. Kennedy J. C., Hawkins R. J.: Swimmers shoulder. Phys. Sports Med. 1974. 2. (4): 34-38.

7. Kluemper M., Uhl T., Hazelrigg H.: Effect of stretching and strengthening shoulder muscle on forward shoulder posture in competitive swimmers. J. Sport Rehabil. 2006. 15. (1): 58-70. https://doi.org/10.1123/isr.15.1.58

8. Krüger K., Stüwer K., Michaud M.: A evidence-based shoulder injury prevention intervention for competitive swimmers. Professional assignment Projet III-2. 2010.

9. Maor M. B., Ronin T., Kalichman L.: Scapular dyskinesis among competitive swimmers. J. Bodyw. Mov. Therap. 2017.21. (3): 633-636. https://doi.org/10.1016/j.jbmt.2016.11.011

10. Rátgéber L., Molics B.: A prevenció szintjei a sportban. In: Sportsérülések primér prevenciója. Szerk. Rátgéber L. Pécs, PTE ETK. 2015. 1. fejezet. 9-11. $p$.

11. Scovazzo M. L., Browne A., Pink M., Jobe F. W., Kerrigan J.: The painful shoulder during freestyle swimming. An electromyographic cimematographic analysis of twelve muscles. Am. J. Sports Med. 1991. 19. (6): $577-582$. https://doi.ora/10.1177/036354659101900604

12. Somhegyi A.: A biomechanikailag helyes testtartás kialakitását, automatizálását és fenntartását szolgáló mozgásanyag beépitése a testnevelésbe. Népegészségügy. 2014. 92. (1): 11-19.

13. Szendrö G., Mayer Á., Schmidtka-Várnagy A., Törös K., Kováts T., Zomborszky M.: Úszással összefüggő mozgásszervi problémák, a vállfájdalom és rizikófaktorainak elöfordulási gyakorisága 11-13 éves tehetséges versenyúszó gyermekek körében. Fizioterápia. 2017. (3): 3-8.

14. Tate A., Turner G. N., Knab S. E., Jorgensen C., Strittmatter A., Michener L. A.: Risk factor associated with shoulder pain and disability across the lifespan of competitive swimmers. J. Athletic Training. 2012. 47. (2): $149-158$. https://doi.org/10.4085/1062-6050-47.2.149

15. Tovin B. J.: Prevention and treatment of swimmer's shoulder. N. Am. J. Sports Phys. Ther. 2006. 1. (4): $166-175$.

16. Walker H., Gabbe B., Wajswelner H., Blanch P., Bennel K.: Shoulder pain in swimmers: A 12-month prospective cohort study of incidence and risk factors. Phys. Ther. Sport. 2012. 13. (4): 243-249. https://doi.org/10.1016/i.ptsp.2012.01.001

17. Wanivenhaus F., Fox A. J. S., Chaudhury S., Rodeo S. A.: Epidemiology of injuries and prevention strategies in competitive swimmers. Sports Health, 2012. 4. (3): 246-251. https://doi.org/10.1177/1941738112442132

\section{Szabó Dorottya}

Pécsi Tudományegyetem ÁOK, Sportmedicina Tanszék

7632 Pécs, Akác u. 1. 